\title{
New records of Hierodula transcaucasica Brunner von Wattenwyl, 1878 (Mantodea) from Bulgaria
}

\author{
Boyan Zlatkov ${ }^{1}$, Stanislav Stefanov ${ }^{2}$, Victor Gashtarov ${ }^{3}$, Vladislav Vergilov ${ }^{4}$
}

(1) Institute of Biodiversity and Ecosystem Research, Bulgarian Academy of Sciences, 1 Tsar Osvoboditel Blvd, 1000 Sofia, Bulgaria,bzlatkov@gmail.com; https://orcid.org/0000-0002-5704-1634

(2) 23 St Kliment Ohridski Street, 3400 Montana, Bulgaria

(3) P.O. Box 4701000 Sofia, Bulgaria, vgashtarov@gmail.com

(4) National Museum of Natural History, Bulgarian Academy of Sciences, 1 Tsar Osvoboditel Blvd, 1000 Sofia, Bulgaria, vladislav8807@gmail.com; https://orcid.org/0000-0002-7464-2263

\begin{abstract}
New localities of Hierodula transcaucasica Brunner von Wattenwyl, 1878 from Bulgaria and illustrations of the species are provided.
\end{abstract}

Keywords: distribution, invasive insect, Mantodea

\section{Introduction}

The mantis Hierodula transcaucasica Brunner von Wattenwyl, 1878 was firstly reported for Bulgaria in 2019 from the southern part of the country, near Pazardzhik Town (Romanowski et al., 2019). Since then, many new observations from the country have been published in the social media (from Shumen, Stara Zagora, Tsarevo, Plovdiv, Kresna and probably more locations), but none of them in a scientific journal. Here we provide two new localities from northern and another two from southern Bulgaria.

\section{Methods}

The insects were observed in the field and some collected by hand. The three female specimens from
Oryahovo were killed using chloroform, eviscerated and filled with cotton wool, pinned and dried. They were preserved in the collection of the National Museum of Natural History at the Bulgarian Academy of Sciences, Sofia, Bulgaria. Further, one female was dried and preserved in the personal collection of $\mathrm{V}$. Gashtarov. The figures in the paper were edited with Illustrator and Photoshop (Adobe Inc.). For representation of distribution, a template map from Abadjiev (2001) was used.

\section{Results and discussion}

The species was recorded from the following localities (Fig. 1):

1 ㅇ, Bulgaria, Oryahovo, N 43.7366 ${ }^{\circ}$ E $23.9755^{\circ}$, 24.ix.2020; 2 우, ibid., 28.ix.2020, leg. S. Stefanov 


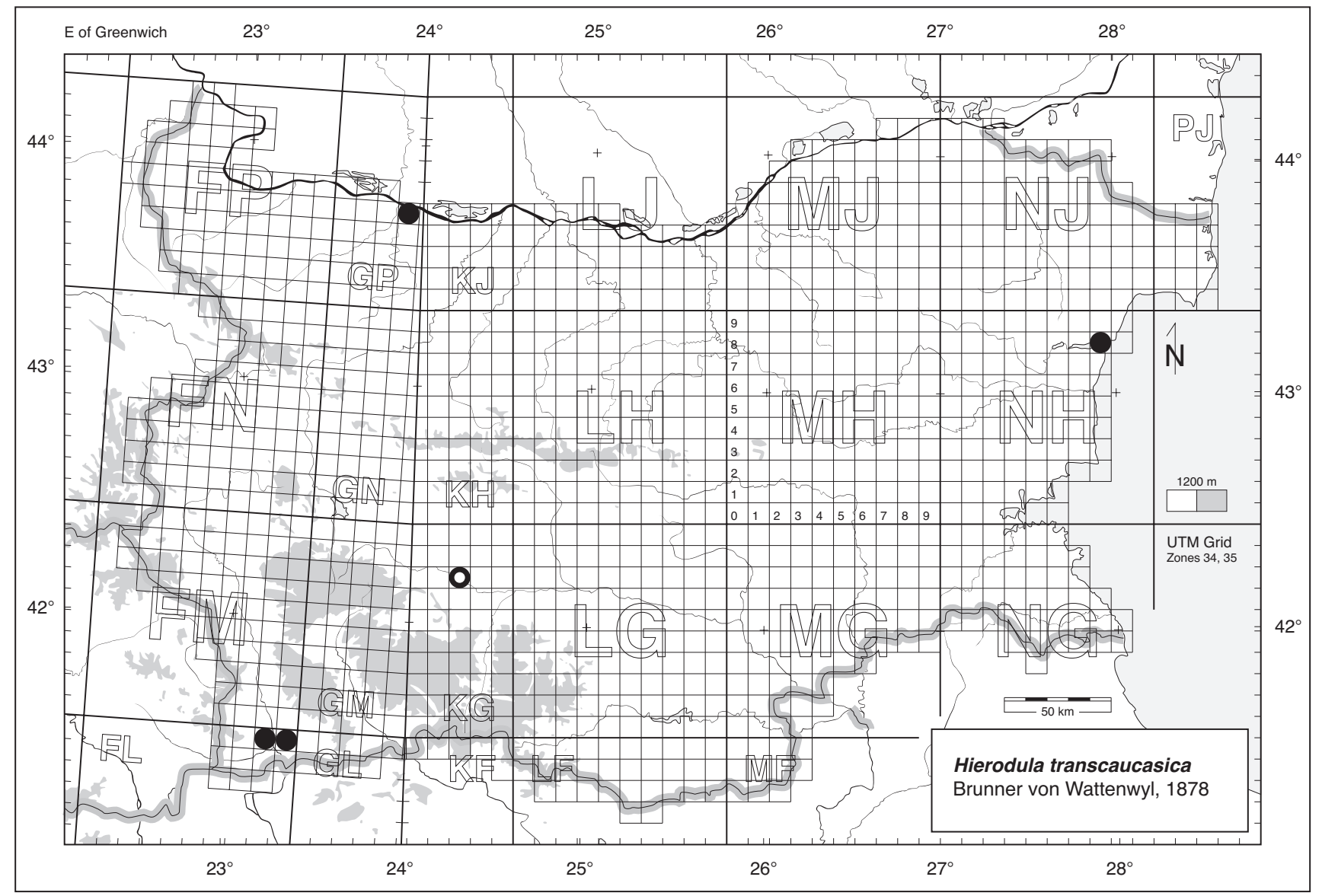

Fig. 1. Distribution of Hierodula transcaucasica Brunner von Wattenwyl, 1878 in Bulgaria. New localities are presented with black circles, previously published record - with empty circle. Map courtesy by S. Abadjiev.

(Fig. 2); 1 nymph, Bulgaria, Varna, N 43.2137, E 27.9431 ${ }^{\circ}$, 21.viii.2020 (observation B. Zlatkov); 1 , Bulgaria, Rupite area near Petrich, N 41.4587, E 23.2616, 12.x.2020 (observation V. Gashtarov); 1 웅, Bulgaria, Novo Konomladi, N $41.4588^{\circ}$ E $23.3342^{\circ}$, 8.ix.2020, leg. V. Gashtarov.

Apart from Bulgaria, H. transcaucasica is known from Iran, Afghanistan, Caucasus, Crimea, Ukraine, Central Asia, Turkey, Greece, and Albania (Battiston et al., 2018; van der Heyden, 2018). Over the past few years, an ongoing debate suggests that $H$. transcaucasica and H. tenuidentata Saussure, 1869 maybe are synonyms (Battison et al., 2018). If this assumption is correct, the valid name of the taxon should be $H$. tenuidentata and its range would cover a very large area from India and Central Asia to Western Europe (Battiston et al., 2018; Moulin, 2020). The new findings from our country suggest that $H$. transcaucasica is going to be a common and widely distributed spe- cies throughout Bulgaria. The impact of this new and apparently invasive species on the local fauna is yet unknown and its eventual assessment would be highly desirable.

\section{References}

Abadjiev S. 2001 An Atlas of the Distribution of the Butterflies in Bulgaria (Lepidoptera: Hesperioidea \& Papilionoidea). Pensoft Publishers, SofiaMoscow, 335 pp.

Battiston R., Leandri F., di Pietro W., Andria S. 2018 The Giant Asian Mantis Hierodula tenuidentata Saussure, 1869 spreads in Italy: a new invasive alien species for the European fauna? (Insecta Mantodea). Biodiversity Journal 9 (4): 399-404. https://doi.org/10.31396/biodiv. jour.2018.9.4.399.404 


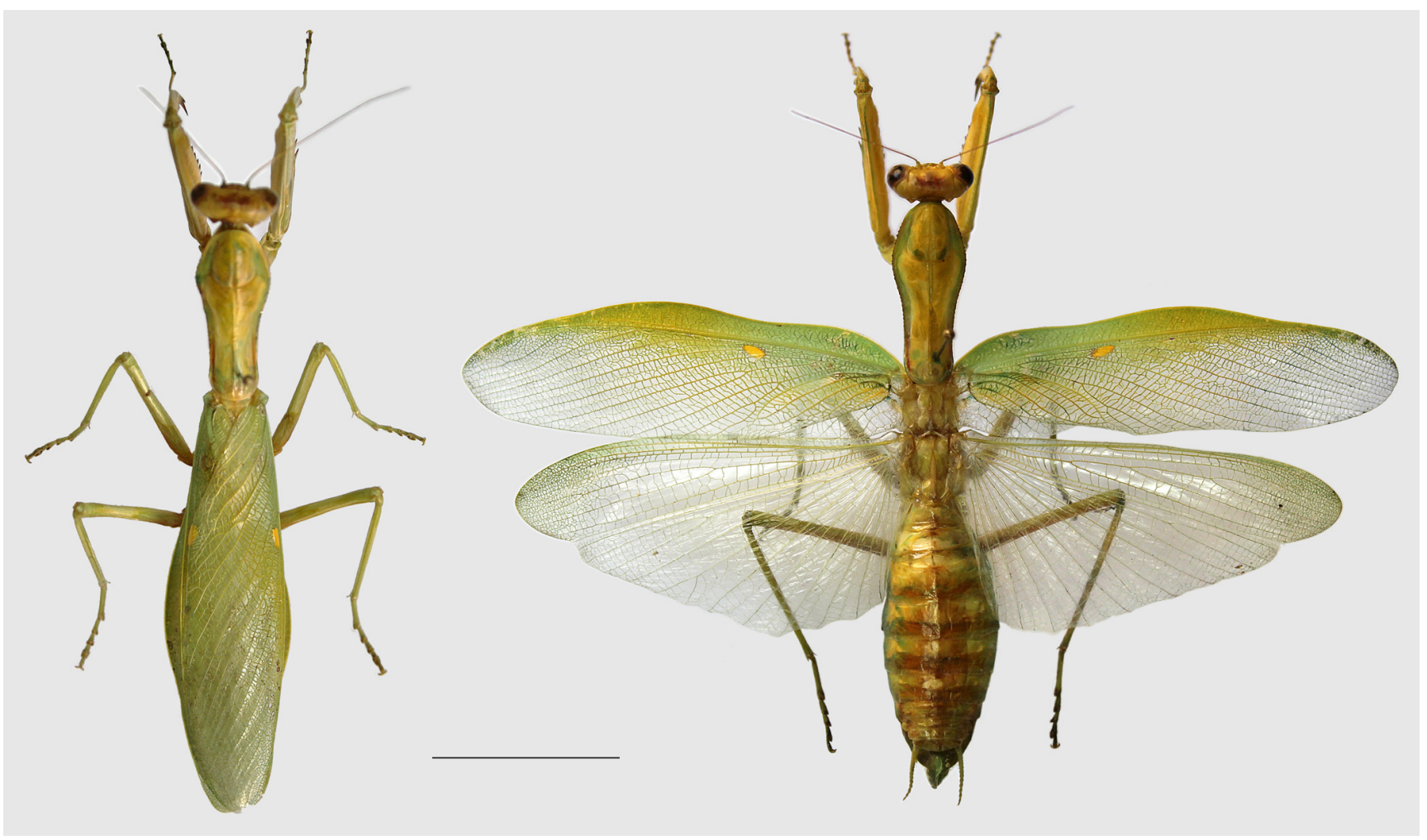

Fig. 2. Hierodula transcaucasica Brunner von Wattenwyl, 1878. Females from Bulgaria, Oryahovo. Scale line $=2 \mathrm{~cm}$.

Moulin N. 2020 When Citizen Science highlights alien invasive species in France: the case of Indochina mantis, Hierodula patellifera (Insecta, Mantodea, Mantidae). Biodiversity Data Journal 8: e46989. https://doi.org/10.3897/BDJ.8.e46989

Romanowski J., Battiston R., Hristov G. 2019 First records of Hierodula transcaucasica Brunner von Wattenwyl, 1878 (Mantodea: Mantidae) in the Balkan peninsula. Acta Zoologica Bulgarica 71 (2): 297-300. van der Heyden T. 2018 First record of Hierodula transcaucasica Brunner von Wattenwyl (Mantodea: Mantidae: Mantinae: Paramantini) in Albania. Revista Chilena de Entomología 44 (4): 407-409. 